\title{
KONSUMSI IKAN PADA IBU HAMIL DAN KAITANNYA DENGAN OUTCOME KELAHIRAN
}

\author{
Fish Consumption in Pregnant Women and Its Relation to Birth Outcome \\ Rendra Kusuma, Ali Khomsan, Lilik Kustiyah \\ Departemen Gizi Masyarakat, Fakultas Ekologi Manusia, Institut Pertanian Bogor \\ (rendrakus@gmail.com)
}

\begin{abstract}
ABSTRAK
Konsumsi ikan ibu hamil yang rendah menjadi faktor risiko yang kuat pada kejadian persalinan prematur dan bayi berat lahir rendah. Tujuan dari penelitian ini mengetahui faktor yang memengaruhi outcome kelahiran. Penelitian ini didanai oleh Neys-van Hoogstraten Foundation. Desain penelitian ini adalah cohort study dengan jumlah subjek sebanyak 41 di Kecamatan Lenteng dan 38 ibu hamil di Kecamtan Kalianget, Kabupaten Sumenep. Data usia, pendidikan, pendapatan, ukuran rumah tangga, berat badan pra-hamil, dan paritas ibu diperoleh dengan wawancara menggunakan kuesioner, tinggi badan ibu menggunakan microtoise, asupan energi menggunakan recall $2 \times 24$ jam, konsumsi ikan menggunakan semi-quantitative food frequency questionnaire. Berat, panjang, dan lingkar kepala lahir bayi berdasarkan catatan bidan. Analisis data menggunakan korelasi pearson dan regresi linier berganda. Hasil penelitian menunjukkan rata-rata konsumsi ikan ibu sebesar 61,8 gram. Rata-rata berat, panjang, dan lingkar kepala bayi lahir sebesar 3090,5 gram, 49,1 sentimeter, dan 33,3 sentimeter. Terdapat hubungan yang signifikan antara konsumsi ikan dan tinggi badan ibu dengan berat dan panjang lahir bayi. Terdapat hubungan yang signifikan antara konsumsi ikan ibu dengan lingkar kepala lahir bayi. Konsumsi ikan dan tinggi badan ibu menjadi faktor yang memengaruhi berat lahir bayi. Konsumsi ikan menjadi faktor yang memengaruhi panjang dan lingkar kepala lahir bayi.
\end{abstract}

Kata kunci : Konsumsi, ikan, outcome kelahiran

\section{ABSTRACT}

Low fish consumption can be a strong risk factor for incidence of preterm and low birth weight.1.2 The aim of this research was to determine factors that affect infant outcome. The study was founded by Neys-van Hoogstraten Foundation. The design of this research was a cohort study with the number of subjects as many as 41 in Lenteng Subdistrict and 38 pregnant women in Kalianget Subdistrict, Sumenep district. The data of the age, education, income, household size, pre-pregnancy weight, and parity were obtained using questionnaires, maternal height using microtoise, energy intake using $2 x 24$ hours recall, fish consumption using semi-quantitative food frequency questionnaire. The data of weight, length, and birth circumference based on midwife's notes. The data analysis using pearson correlation and multiple linear regression. The results showed that average of pregnant women fish consumption was 61.8 grams. The average of weight, length, and circumference were 3090.5 grams, 49.1 centimeters, and 33.3 centimeters. There were significant relationship between fish consumption and maternal height with weight and length birth. There were significant relationship between maternal fish consumption with birth circumference. Maternal fish consumption and maternal height become factors that affect birth weight. Maternal fish consumption become factors that affect length and birth circumference.

Keywords : Consumption, fish, birth outcome 


\section{PENDAHULUAN}

Studi Diet Total menunjukkan bahwa tingkat kecukupan protein ibu hamil yang berkategori sangat kurang $(<80 \%$ Angka Kecukupan Protein=AKP) dijumpai pada 49,6\% di perkotaan dan $55,7 \%$ di perdesaan. ${ }^{3}$ Pada tahun 2013 prevalensi Kurang Energi Kronis (KEK) pada ibu hamil sebesar 24,2\%. Sementara prevalensi Bayi Berat Lahir Rendah (BBLR) sebesar 10,2\% dan tergolong kedalam kategori prevalensi tinggi. ${ }^{4}$

Indonesia masih tergantung pada impor untuk pemenuhan protein penduduknya. Impor daging sapi tertinggi terjadi pada tahun 2014 yaitu sebesar 246.609 ton atau setara US\$ 681.229 juta. Sementara konsumsi daging sapi rata-rata hanya sebesar 2,08 kg/kap/tahun, daging ayam ras 3,98 $\mathrm{kg} / \mathrm{kap} / \mathrm{tahun}$ dan ayam buras $0,49 \mathrm{~kg} / \mathrm{kap} / \mathrm{tahun}$. Untuk telur, baik konsumsi maupun impornya mengalami peningkatan sampai tahun 2014 walaupun konsumsinya hanya sebesar $8,9 \mathrm{~kg} / \mathrm{kap} / \mathrm{ta}-$ hun. Konsumsi susu hanya sebesar 14,6 liter/kap/ tahun pada tahun 2013 dengan $79,63 \%$ penyediaan susu nasional dilakukan dengan cara impor..$^{5-8}$

Sebagai negara dengan potensi perikanan yang tinggi seharusnya Indonesia dapat menjadikan ikan sebagai sumber protein utama, sehingga dapat menghemat biaya untuk impor sumber protein yang lain. Volume produksi perikanan tangkap Indonesia tahun 2014 di laut sebesar 6.037.654 ton dan di perairan umum sebesar 446.692 ton, ${ }^{9}$ sedangkan konsumsi ikan di Indonesia hanya sebesar 32,25 kg/kap/tahun..$^{10}$ Adapun konsumsi ikan di Sumenep hanya sebesar $31,28 \mathrm{~kg} / \mathrm{kap} /$ tahun. ${ }^{11}$ Sementara itu angka kematian ibu di Kabupaten Sumenep sebesar 63,71 per 100.000 kelahiran hidup dan kejadian BBLR sebanyak 360 bayi dari 15.696 bayi lahir hidup (2,95\%). ${ }^{12}$

Penelitian sebelumnya menyebutkan bahwa konsumsi ikan yang rendah menjadi faktor risiko yang kuat untuk kejadian persalinan prematur dan BBLR. ${ }^{1,2}$ Hubungan konsumsi ikan dengan berat badan mungkin karena lemak ikan yang terkandung didalamnya. ${ }^{13}$ Selain itu, konsumsi makanan laut yang tinggi selama kehamilan berhubungan dengan perkembangan syaraf anak yang menguntungkan dan sebaliknya ibu yang mengonsumsi makanan laut rendah maka perkembangan syaraf anaknya menjadi kurang optimal. ${ }^{14,15}$

Hasil penelitian sebelumnya menunjukkan keuntungan mengonsumsi ikan pada saat hamil, tetapi disatu sisi kontribusi konsumsi ikan terhadap total konsumsi protein masih rendah. Kontribusi konsumsi protein ikan pada ibu hamil hanya $13,7 \%$ terhadap total konsumsi protein. ${ }^{16}$ Berdasarkan paparan tersebut, diperlukan sebuah penelitian untuk mengetahui konsumsi ikan ibu hamil dan faktor yang memengaruhi outcome kelahiran, khususnya di Kabupaten Sumenep.

\section{BAHAN DAN METODE}

Penelitian ini menggunakan desain cohort study untuk mempelajari hubungan antara exposure dengan outcome. Penelitian bertempat di Kecamatan Lenteng dan Kecamatan Kalianget, Kabupaten Sumenep, pada bulan Februari hingga Juni 2017. Penelitian ini merupakan bagian dari penelitian Dietary Intake, Nutritional Status, Traditional Beliefs and Practices of Pregnant Women in Madura Island yang didanai oleh Neys-van Hoogstraten Foundation. ${ }^{17}$ Penelitian ini telah mendapatkan persetujuan etik dari Komisi Etik Penelitian Kesehatan Universitas Airlangga Surabaya dengan Nomor: 1-KEPK, tanggal 3 Januari 2017. Populasi dari penelitian adalah ibu hamil yang berada di Kecamatan Lenteng dan Kecamatan Kalianget yang terdaftar di puskesmas setempat. Cara penentuan contoh penelitian menggunakan rumus besar sampel untuk estimasi rata-rata dua kelompok tidak berpasangan dan menggunakan data penelitian sebelumnya dalam perhitungan. ${ }^{18,19}$ Berdasarkan perhitungan didapatkan jumlah minimum contoh sebanyak $38 \mathrm{ibu}$ hamil di masing-masing daerah non-pesisir dan pesisir.

Data primer didapat dari wawancara secara langsung meliputi usia saat hamil, pendidikan, pendapatan, ukuran rumah tangga, berat badan pra-hamil, paritas ibu menggunakan kuesioner, pengukuran tinggi badan ibu menggunakan microtoise, asupan energi, protein, lemak ibu menggunakan recall 2x24 jam, konsumsi ikan ibu menggunakan semi-quantitative food frequency questionnaire $(S Q-F F Q)$. Data sekunder yang meliputi berat, panjang, dan lingkar kepala lahir bayi (outcome kelahiran) ditanyakan kepada bidan desa. Variabel dependen dari penelitian ini adalah berat, panjang, dan lingkar kepala lahir bayi sedangkan variabel independen meliputi konsumsi ikan ibu serta faktor-faktor yang dapat berpotensi sebagai 
perancu diantaranya usia, pendidikan, paritas, gi badan ibu. ${ }^{20,21}$ Data diolah menggunakan Micasupan energi total, indeks massa tubuh serta ting- rosoft Excel 2013 dan dianalisis secara deskriptif

Tabel 1. Sebaran Karakteristik Ibu Berdasarkan Wilayah Tempat Tinggal

\begin{tabular}{|c|c|c|c|}
\hline \multirow{3}{*}{ Karakteristik } & Non Pesisir & Pesisir & Total \\
\hline & $\bar{x} \pm \mathbf{S D}$ & $\bar{x} \pm \mathbf{S D}$ & $\bar{x} \pm$ SD \\
\hline & $n(\%)$ & $n(\%)$ & $n(\%)$ \\
\hline Usia Ibu (tahun) & $26.5 \pm 5.4$ & $27.5 \pm 6.6$ & $27.0 \pm 5.9$ \\
\hline$<20$ & $2(4.9)$ & $4(10.5)$ & $6(7.6)$ \\
\hline $20-35$ & $36(87.8)$ & $30(78.9)$ & $66(83.5)$ \\
\hline$>35$ & $3(7.3)$ & $4(10.5)$ & $7(8.9)$ \\
\hline Pendidikan Ibu (tahun) & $26.5 \pm 5.4$ & $27.5 \pm 6.6$ & $9.9 \pm 4.0$ \\
\hline Tidak Sekolah & $2(4.9)$ & $3(7.9)$ & $5(6.3)$ \\
\hline SD & $13(31.7)$ & $11(28.9)$ & $24(30.4)$ \\
\hline SMP & $5(12.2)$ & $6(15.8)$ & $11(13.9)$ \\
\hline SMA & $13(31.7)$ & $12(31.6)$ & $25(31.6)$ \\
\hline PT & $8(19.5)$ & $6(15.8)$ & $14(17.7)$ \\
\hline Sosial Ekonomi (Rp 000) & $718 \pm 1578$ & $867 \pm 1307$ & $790 \pm 14470$ \\
\hline Miskin & $17(41.5)$ & $7(18.4)$ & $24(30.4)$ \\
\hline Tidak Miskin & $24(58.5)$ & $31(81.6)$ & $25(69.6)$ \\
\hline Ukuran Rumah Tangga (orang) & $4.5 \pm 1.5$ & $4.0 \pm 1.7$ & $4.3 \pm 1.6$ \\
\hline Kecil $(2-4)$ & $21(51.2)$ & $25(65.8)$ & $46(58.2)$ \\
\hline Sedang $(5-7)$ & $16(39.0)$ & $10(26.3)$ & $26(32.9)$ \\
\hline $\operatorname{Besar}(\geq 8)$ & $4(9.8)$ & $3(7.9)$ & $7(8.9)$ \\
\hline Konsumsi Ikan (g/hari) & $45.6 \pm 48.4$ & $79.4 \pm 53.8$ & $61.8 \pm 53.5$ \\
\hline $0-5$ & $6(14.6)$ & $1(2.6)$ & $7(8.9)$ \\
\hline$>5-20$ & $6(14.6)$ & $6(15.8)$ & $12(15.2)$ \\
\hline$>20-40$ & $12(29.3)$ & $2(5.3)$ & $14(17.7)$ \\
\hline$>40-60$ & $4(9.8)$ & $7(18.4)$ & $11(13.9)$ \\
\hline$>60$ & $13(31.7)$ & $22(57.9)$ & $35(44.3)$ \\
\hline Asupan Energi (Kal/hari) & $1340 \pm 386$ & $1271 \pm 407$ & $1307 \pm 395$ \\
\hline defisit tingkat berat & $30(73.2)$ & $30(78.9)$ & $60(75.9)$ \\
\hline defisit tingkat sedang & $3(7.3)$ & $3(7.9)$ & $6(7.6)$ \\
\hline defisit tingkat ringan & $6(14.6)$ & $1(2.6)$ & $7(8.9)$ \\
\hline normal & $2(4.9)$ & $4(10.5)$ & $6(7.6)$ \\
\hline \multicolumn{4}{|c|}{ Kontribusi Energi dan Zat Gizi dari Ikan } \\
\hline Energi $(\%)$ & $5.3 \pm 5.6$ & $6.0 \pm 5.9$ & $5.7 \pm 5.7$ \\
\hline Protein $(\%)$ & $23.1 \pm 21.1$ & $24.8 \pm 20.9$ & $23.9 \pm 20.9$ \\
\hline Lemak $(\%)$ & $2.1 \pm 2.6$ & $6.9 \pm 11.2$ & $4.4 \pm 8.3$ \\
\hline IMT Pra Hamil $\left(\mathrm{kg} / \mathrm{m}^{2}\right)$ & $22.6 \pm 3.6$ & $22.7 \pm 4.0$ & $22.6 \pm 3.8$ \\
\hline Kurus & $2(4.9)$ & $4(10.5)$ & $6(7.6)$ \\
\hline Normal & $36(87.8)$ & $30(78.9)$ & $66(83.5)$ \\
\hline Gemuk & $3(7.3)$ & $4(10.5)$ & $7(8.9)$ \\
\hline Tinggi Badan Ibu (cm) & $149.7 \pm 5.7$ & $153.3 \pm 4.9$ & $151.4 \pm 5.6$ \\
\hline$<150$ & $23(56.1)$ & $8(21.1)$ & 31(39.2) \\
\hline$\geq 150$ & $18(43.9)$ & $30(78.9)$ & $48(60.8)$ \\
\hline Paritas & $0.76 \pm 0.8$ & $0.89 \pm 1.0$ & $0.82 \pm 0.9$ \\
\hline Nullipara (0 kali) & $18(43.9)$ & $17(44.7 \%)$ & $35(44.3)$ \\
\hline Primipara (1 kali) & $16(39.0)$ & $11(28.9)$ & $27(34.2)$ \\
\hline Multipara ( $\geq 2$ kali) & $7(17.1)$ & $10(26.6)$ & $17(21.5)$ \\
\hline
\end{tabular}

Sumber : Data Primer, 2017 
dan statistik menggunakan SPSS version 16.0 for Windows.

\section{HASIL}

Sebaran karakteristik ibu berdasarkan wilayah tempat tinggal ditunjukkan pada Tabel 1 . Rata-rata usia ibu 27 tahun dan usia ibu di wilayah pesisir cenderung lebih tinggi dibanding wilayah non-pesisir. Sebagian besar ibu menamatkan pendidikan SD (30,4\%) dan SMA (31,6\%) dan rata-rata lama pendidikan di wilayah non-pesisir cenderung lebih tinggi dibanding wilayah pesisir. Rata-rata pendapatan per kapita ibu di wilayah pesisir cenderung lebih tinggi jika dibandingkan dengan wilayah non-pesisir dan secara keseluruhan rata-rata pendapatan per kapita ibu sebesar 790.000 \pm 1.447 .000 . Terdapat sebagian ibu yang berada dibawah garis kemiskinan. Ibu yang tergolong miskin di wilayah pesisir lebih rendah dibanding wilayah non-pesisir. Sebagian besar ibu di kedua wilayah tergolong kedalam keluarga kecil.

Uji beda $t$ menunjukkan ada perbedaan yang signifikan konsumsi ikan ibu di wilayah non-pesisir dan pesisir $(p<0,01)$. Konsumsi ikan ibu di wilayah pesisir $(79,4 \pm 53,8 \mathrm{~g}$ /hari) lebih tinggi jika dibandingkan dengan di wilayah non-pesisir (45,6 \pm 48,4 g/hari). Konsumsi ikan ibu yang lebih dari 40 gram/hari lebih banyak di wilayah pesisir $(75,9 \%)$ di banding wilayah non pesisir $(41,5 \%)$. Sedangkan untuk kontribusi asupan zat gizi dari ikan terhadap asupan total, hanya kontribusi lemak ikan terhadap asupan lemak total yang berbeda secara signifikan $(p<0,05)$ antar dua wilayah penelitian. Kontribusi asupan lemak dari ikan ter-

Tabel 2. Sebaran Outcome Kelahiran Berdasarkan Wilayah Tempat Tinggal

\begin{tabular}{lccc}
\hline \multirow{2}{*}{ Outcome Kelahiran } & Non Pesisir & Pesisir & Total \\
\cline { 2 - 4 } & $\bar{x} \pm \mathbf{S D}$ & $\bar{x} \pm \mathbf{S D}$ & $\bar{x} \pm$ SD \\
\cline { 2 - 4 } & $\mathbf{n}(\mathbf{\%})$ & $\mathbf{n}(\mathbf{\%})$ & $\mathbf{n}(\mathbf{\%})$ \\
\hline Berat badan bayi (g) & $2991.5 \pm 364.5$ & $3197.4 \pm 398.9$ & $3090.5 \pm 392.9$ \\
$\quad<2500$ & $2(4.9)$ & $0(0.0)$ & $2(2.5)$ \\
$2500-3999$ & $39(95.1)$ & $35(92.1)$ & $74(93.7)$ \\
$>4000$ & $0(0.0)$ & $3(7.9)$ & $3(3.8)$ \\
Panjang badan bayi (cm) & $49.1 \pm 1.6$ & $49.1 \pm 1.2$ & $49.1 \pm 1.4$ \\
$<48$ & $2(4.9)$ & $4(10.5)$ & $6(7.6)$ \\
$48-52$ & $38(92.7)$ & $34(89.5)$ & $72(91.1)$ \\
$>52$ & $1(2.4)$ & $0(0.0)$ & $1(1.3)$ \\
Lingkar kepala bayi (cm) & $32.7 \pm 1.3$ & $34.0 \pm 1.2$ & $33.3 \pm 1.4$ \\
$<33$ & $17(41.5)$ & $6(15.8)$ & $23(29.1)$ \\
$33-37$ & $24(58.5)$ & $32(84.2)$ & $56(70.9)$ \\
\hline
\end{tabular}

Sumber : Data Primer, 2017

Tabel 3. Hasil Uji Hubungan Variabel Independen dengan Outcome Kelahiran

\begin{tabular}{lcccccc}
\hline \multirow{2}{*}{$\begin{array}{l}\text { Variabel Independen } \\
\text { Usia ibu }\end{array}$} & \multicolumn{2}{c}{$\begin{array}{c}\text { Berat badan lahir } \\
\text { (Y1) }\end{array}$} & \multicolumn{2}{c}{$\begin{array}{c}\text { Panjang badan } \\
\text { lahir (Y2) }\end{array}$} & \multicolumn{2}{c}{$\begin{array}{c}\text { Lingkar kepala } \\
\text { lahir (Y3) }\end{array}$} \\
\cline { 2 - 7 } & p-value & r & p-value & r & p-value & r \\
Indeks massa tubuh ibu & 0.917 & -.012 & 0.126 & -0.173 & 0.188 & 0.150 \\
Tinggi badan ibu & 0.885 & 0.017 & 0.739 & -0.038 & 0.403 & 0.095 \\
Paritas & $0.005^{* *}$ & 0.310 & $0.047 *$ & 0.224 & 0.142 & 0.167 \\
Pendidikan ibu & 0.920 & 0.011 & 0.798 & -0.029 & 0.290 & 0.120 \\
Total asupan energi ibu & 0.894 & -0.015 & 0.768 & 0.034 & 0.886 & 0.016 \\
Konsumsi ikan ibu & 0.735 & -0.039 & 0.400 & -0.096 & 0.907 & -0.013 \\
\hline
\end{tabular}

* Berhubungan signifikan pada $\mathrm{p}<0.05$

** Berhubungan signifikan pada $\mathrm{p}<0.01$ 
hadap asupan lemak total signifikan lebih tinggi di wilayah pesisir dibandingkan wilayah non-pesisir. Rata-rata asupan energi total ibu sebesar $1.307 \pm$ $395 \mathrm{Kal} /$ hari, dan sebagian besar $(75,9 \%)$ mengalami kekurangan energi tingkat berat. Rata-rata Indeks Massa Tubuh (IMT) pra-hamil ibu sebesar 22,6 $\pm 3,8$ (normal), walaupun terdapat ibu yang termasuk kategori kurus $(7,6 \%)$ dan gemuk

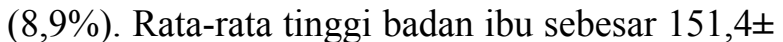
$5,6 \mathrm{~cm}$, tetapi ada sebesar $39,2 \%$ ibu yang berkategori pendek $(<150 \mathrm{~cm})$. Rata-rata ibu melahirkan sebanyak 0,82 $\pm 0,9$ dan sebagian besar ibu belum pernah melahirkan (nullipara) $(44,3 \%)$. Sementara itu ibu yang pernah melahirkan satu kali sebesar 34,2\% dan yang melahirkan lebih dari dua kali sebesar $21,5 \%$. Keseluruhan karakteristik ibu berdasarkan wilayah tempat tinggal ditunjukan pada Tabel 1.

Uji beda $t$ menunjukkan terdapat perbedaan yang signifikan berat lahir bayi di wilayah non-pesisir dan pesisir $(\mathrm{p}<0,05)$. Rata-rata berat lahir bayi sebesar $3090,5 \pm 392,9$ gram, dan rata-rata berat lahir bayi di wilayah pesisir signifikan lebih tinggi dari pada wilayah non-pesisir. Di wilayah non-pesisir terdapat $4,9 \%$ bayi dengan kategori BBLR $(<2.500 \mathrm{~g})$ sedangkan di pesisir tidak ada. Bayi yang lahir dengan berat badan lebih 4.000 gram hanya terdapat di wilayah pesisir $(7,9 \%)$. Uji beda $t$ menunjukkan tidak terdapat perbedaan panjang lahir bayi di wilayah non-pesisir dan pe$\operatorname{sisir}(p>0,05)$. Rata-rata panjang lahir bayi secara

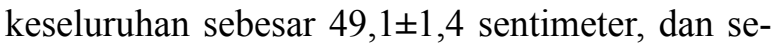
bagian besar tergolong kedalam kategori normal $(91,1 \%)$. Uji beda $t$ menunjukkan ada perbedaan yang signifikan lingkar kepala lahir di wilayah non-pesisir dan pesisir $(\mathrm{p}<0,01)$. Rata-rata lingkar kepala bayi yang dilahirkan secara keseluruhan sebesar 33,3 $\pm 1,4$ sentimeter, dan rata-rata lingkar kepala lahir bayi di wilayah pesisir lebih tinggi dibandingkan non-pesisir. Sebagian besar bayi di wilayah non-pesisir lingkar kepalanya $<33 \mathrm{~cm}$ $(41,5 \%)$ seperti yang ditunjukkan pada Tabel 2.

Hasil uji korelasi menunjukkan bahwa usia ibu tidak berhubungan dengan berat lahir bayi $(\mathrm{p}=0,917 ; \mathrm{r}=-0,012)$, panjang lahir bayi $(\mathrm{p}=0,126$; $\mathrm{r}=-0,173)$, dan lingkar kepala lahir bayi $(\mathrm{p}=0,188$; $\mathrm{r}=0,150$ ). Hasil uji korelasi menunjukkan IMT pra-hamil ibu tidak berhubungan dengan berat lahir bayi $(\mathrm{p}=0,885 ; \mathrm{r}=0,017)$, panjang lahir bayi $(\mathrm{p}=0,739 ; \mathrm{r}=-0,038)$, dan lingkar kepala lahir bayi $(p=0,403 ; r=0,095)$. Sementara itu tinggi badan ibu berhubungan positif dengan berat $(\mathrm{p}=0,005$; $\mathrm{r}=0,310)$ dan panjang lahir bayi $(\mathrm{p}=0,047$; $\mathrm{r}=0,224)$, tetapi tidak berhubungan dengan lingkar kepala lahir bayi ( $p=0,142 ; r=0,167)$. Jumlah anak yang pernah dilahirkan (paritas) tidak berhubungan dengan berat lahir bayi $(p=0,920$; $\mathrm{r}=0,011)$, panjang lahir bayi $(\mathrm{p}=0,798 ; \mathrm{r}=-0,029)$, dan lingkar kepala lahir bayi $(\mathrm{p}=0,290 ; \mathrm{r}=0,120)$. Begitupun pendidikan ibu tidak memiliki hubungan dengan berat lahir bayi ( $\mathrm{p}=0,894 ; \mathrm{r}=-0,015)$, panjang lahir bayi $(\mathrm{p}=0,768 ; \mathrm{r}=0,034)$, dan lingkar kepala lahir bayi $(p=0,886 ; r=0,016)$. Asupan energi ibu tidak berhubungan dengan berat lahir bayi $(p=0,735 ; r=-0,039)$, panjang lahir bayi $(p=0,400$; $\mathrm{r}=-0,096)$, maupun dengan lingkar kepala lahir bayi ( $p=0,907 ; r=-0,013)$. Konsumsi ikan ibu memiliki hubungan positif dengan berat lahir bayi $(\mathrm{p}=0,000 ; \mathrm{r}=0,348)$, panjang lahir bayi $(\mathrm{p}=0,037$; $\mathrm{r}=0,248$ ), maupun dengan lingkar kepala lahir bayi $(\mathrm{p}=0,039 ; \mathrm{r}=0,302)$ seperti yang ditunjukkan pada Tabel 3.

Hasil regresi linier berganda pada wilayah non-pesisir menunjukkan bahwa konsumsi ikan berpengaruh terhadap berat dan panjang lahir bayi dengan persamaan berturut-turut $Y_{1 \mathrm{a}}=2860,0+2,9 \mathrm{X}$ $\left(\mathrm{R}^{2}=0,147 ; \mathrm{p}=0,013\right)$ dan $\mathrm{Y}_{2 \mathrm{a}}=32,6+0,107 \mathrm{X}_{1}+$ $0,010 \mathrm{X}_{2}\left(\mathrm{R}^{2}=0,248 ; \mathrm{p}=0,004\right)$. Tidak terdapat variabel independen yang berpengaruh terhadap lingkar kepala lahir bayi di wilayah non-pesisir. Sementara itu di wilayah pesisir konsumsi ikan juga berpengaruh terhadap berat lahir bayi dengan persamaan $\mathrm{Y}_{1 \mathrm{~b}}=2995,5+2,5 \mathrm{X} \quad\left(\mathrm{R}^{2}=0,118 ; \mathrm{p}=0,035\right)$. Selain itu ternyata tinggi badan ibu berpengaruh terhadap panjang lahir bayi di pesisir dengan persamaan $\mathrm{Y}_{2 \mathrm{~b}}=51,2-0,075 \mathrm{X} \quad\left(\mathrm{R}^{2}=0,147 ; \mathrm{p}=0,010\right)$. Namun, tidak terdapat variabel independen yang berpengaruh terhadap lingkar kepala lahir bayi di wilayah pesisir. Ada pun secara total (non-pesisir dan pesisir) analisis regresi linier berganda menunjukkan bahwa tinggi badan ibu $\left(\mathrm{X}_{1}\right)$ dan konsumsi ikan ibu $\left(\mathrm{X}_{2}\right)$ dan berpengaruh terhadap berat lahir bayi dengan persamaan $\mathrm{Y}_{1 \mathrm{c}}=102,1+18,6 \mathrm{X}_{1}+$ $2,8 \mathrm{X} 2\left(\mathrm{R}^{2}=0,242 ; \mathrm{p}=0,000\right)$. Sedangkan untuk panjang dan lingkar kepala lahir bayi dipengaruhi oleh konsumsi ikan ibu dengan persamaan berturut-turut $\mathrm{Y}_{2 \mathrm{c}}=48,7+0,006 \mathrm{X}\left(\mathrm{R}^{2}=0,055 ; \mathrm{p}=0,037\right)$ dan $Y_{3 c}=32,9+0,006 X\left(R^{2}=0,054 ; p=0,039\right)$ seperti 
Tabel 4. Hasil Uji Regresi Linier Variabel Independen dengan Outcome Kelahiran

\begin{tabular}{|c|c|c|c|c|c|}
\hline Wilayah & Variabel Y & Model & $\mathbf{R}^{2}$ & B & p value \\
\hline \multirow[t]{3}{*}{ Non-pesisir } & $\mathrm{Y}_{\mathrm{la}}=$ Berat lahir bayi & $\begin{array}{l}\text { Constant } \\
\text { 1.Konsumsi Ikan (g/hari) }\end{array}$ & 0.147 & $\begin{array}{c}2860.0 \\
2.9\end{array}$ & 0.013 \\
\hline & $\mathrm{Y}_{2 \mathrm{a}}=$ Panjang lahir bayi & $\begin{array}{l}\text { Constant } \\
\text { 1. TB ibu } \\
\text { 2. Konsumsi Ikan (g/hari) }\end{array}$ & 0.248 & $\begin{array}{l}32.6 \\
0.107 \\
0.010\end{array}$ & 0.004 \\
\hline & $Y_{3 a}=$ Lingkar kepala lahir bayi & Variable Entered/Removed & & & \\
\hline \multirow[t]{3}{*}{ Pesisir } & $\mathrm{Y}_{\mathrm{lb}}=$ Berat lahir bayi & $\begin{array}{l}\text { Constant } \\
\text { 1.Konsumsi Ikan (g/hari) }\end{array}$ & 0.118 & $\begin{array}{l}2995.5 \\
2.5\end{array}$ & 0.035 \\
\hline & $Y_{2 b}=$ Panjang lahir bayi & $\begin{array}{l}\text { Constant } \\
\text { 1. Usia Ibu }\end{array}$ & 0.147 & $\begin{array}{c}51.2 \\
-0.075\end{array}$ & 0.010 \\
\hline & $Y_{3 b}=$ Lingkar kepala lahir bayi & Variable Entered/Removed & & & \\
\hline \multirow[t]{3}{*}{ Total } & $Y_{1 c}=$ Berat lahir bayi & $\begin{array}{l}\text { Constant } \\
\text { 1. TB ibu } \\
\text { 2. Konsumsi Ikan (g/hari) }\end{array}$ & 0.242 & $\begin{array}{c}102.1 \\
18.6 \\
2.8\end{array}$ & 0.000 \\
\hline & $Y_{2 c}=$ Panjang lahir bayi & $\begin{array}{l}\text { Constant } \\
\text { 1. Konsumsi Ikan (g/hari) }\end{array}$ & 0.055 & $\begin{array}{l}48.7 \\
0.006\end{array}$ & 0.037 \\
\hline & $\mathrm{Y}_{3 \mathrm{c}}=$ Lingkar kepala lahir bayi & $\begin{array}{l}\text { Constant } \\
\text { 1. Konsumsi Ikan (g/hari) }\end{array}$ & 0.054 & $\begin{array}{c}32.9 \\
0.006\end{array}$ & 0.039 \\
\hline
\end{tabular}

yang ditunjukkan pada Tabel 4.

\section{PEMBAHASAN}

Rata-rata konsumsi ikan ibu dibawah konsumsi ikan Kabupaten Sumenep yang sebesar 85,7 gram/kap/hari. ${ }^{11}$ Secara umum ibu yang mengonsumsi ikan lebih dari 40 gram/hari lebih banyak di wilayah pesisir dibanding wilayah non pesisir. Sejalan dengan hal tersebut, kontribusi asupan lemak dari ikan terhadap asupan lemak total di wilayah pesisir signifikan lebih tinggi jika dibandingkan dengan wilayah non pesisir. Akses yang lebih mudah untuk mendapatkan ikan yang diduga menjadi salah satu alasan tingginya konsumsi ikan ibu di wilayah pesisir.

Tidak terdapatnya hubungan antara usia ibu dengan outcome kelahiran diduga karena sebagian besar usia ibu masuk kedalam usia ideal untuk hamil $(83,5 \%)$. Penelitian terdahulu juga menyebutkan bahwa usia ibu tidak berhubungan dengan outcome kelahiran yaitu kejadian BBLR. ${ }^{22}$ Salah satu kehamilan berisiko tinggi dikarenakan usia saat hamil terlalu rendah $(<20$ tahun) dan terlalu tinggi ( $>35$ tahun). ${ }^{23}$ Bahkan usia ibu yang kurang dari 20 tahun memiliki risiko tinggi terhadap kejadian kematian neonatal. ${ }^{24}$
Penelitian terdahulu juga menyatakan bahwa hubungan antara berat lahir dan antropometri anak tidak dapat dijelaskan oleh IMT ibu. ${ }^{25}$ Lingkar kepala dapat dijadikan sebagai proyeksi perkembangan syaraf bayi, tetapi pada penelitian sebelumnya menunjukkan belum cukup bukti yang dapat menyimpulkan bahwa IMT ibu berhubungan dengan perkembangan syaraf bayi. ${ }^{26}$ IMT pra hamil ibu dalam penelitian ini sebagian besar normal $(83,5 \%)$, sehingga dibutuhkan penelitian dengan sampel pembanding di daerah dengan kondisi ibu dengan IMT yang rendah, sedangkan tinggi badan ibu berhubungan dengan berat dan panjang lahir bayi. Hal tersebut sejalan dengan penelitian sebelumnya yang menyatakan bahwa tinggi badan ibu berbanding terbalik dengan kejadian berat badan kurang dan stunting pada anak. ${ }^{27} \mathrm{Hal}$ tersebut berarti dengan peningkatan tinggi badan ibu maka akan terjadi peningkatan berat dan panjang lahir bayi.

Pada penelitian ini tidak terdapat hubungan antara paritas dengan outcome bayi yang dilahirkan. Padahal penelitian sebelumnya menunjukkan ada hubungan yang signifikan antara paritas dan berat lahir, ibu yang sebelumnya belum pernah melahirkan cenderung melahirkan anak 
dengan berat lahir rendah dan lahir prematur. ${ }^{28}$ Tidak terdapatnya hubungan diduga karena bayi dengan berat lahir dibawah 2.500 gram dalam penelitian ini hanya $3,8 \%$, sementara yang dengan berat badan normal sebanyak $93,7 \%$. Pendidikan merupakan salah satu pintu untuk masuknya pengetahuan, salah satunya pengetahuan gizi saat hamil. Harapannya dengan semakin meningkatnya pendidikan akan meningkat pula pengetahuan yang akhirnya berpengaruh pada status gizi ibu dan bayi yang dilahirkan. Namun, dalam penelitian ini tingkat pendidikan ibu tidak memiliki hubungan dengan outcome bayi yang dilahirkan. Hal ini sejalan dengan penelitian sebelumnya yang menunjukkan tidak ada hubungan yang signifikan antara kejadian BBLR dan pendidikan ibu. ${ }^{22}$

Asupan energi ibu tidak berhubungan dengan outcome bayi yang dilahirkan. Hal ini berbeda dengan penelitian sebelumnya yang menyatakan bahwa konsumsi energi berhubungan dengan berat badan lahir. ${ }^{29}$ Namun, dalam penelitian ini menunjukkan bahwa asupan energi yang tinggi tidak selalu berhubungan dengan meningkatnya berat lahir bayi. Rata-rata asupan energi yang lebih tinggi di wilayah non-pesisir tidak diikuti dengan rata-rata berat lahir bayinya.

Konsumsi ikan ibu memiliki hubungan positif dengan berat, panjang, dan lingkar kepala lahir bayi. Penelitian lain menyatakan terdapat hubungan positif antara peningkatan konsumsi ikan ibu dengan berat dan lingkar kepala lahir bayi. ${ }^{20}$ Konsumsi ikan ibu menjadi faktor yang berpengaruh terhadap outcome bayi yang dilahirkan. Seiring dengan meningkatnya konsumsi ikan harian ibu maka akan cenderung meningkatkan berat, panjang, dan lingkar kepala lahir bayi. Bersama dengan tinggi badan ibu, konsumsi ikan memiliki pengaruh terhadap berat lahir bayi. Begitupun terhadap panjang dan lingkar kepala lahir bayi juga dipengaruhi oleh konsumsi ikan ibu.

Konsumsi ikan di wilayah non-pesisir berpengaruh terhadap berat dan panjang lahir bayi, tetapi di wilayah pesisir konsumsi ikan hanya berpengaruh terhadap berat lahir bayi. Hal ini menunjukkan walaupun rata-rata konsumsi ikan di wilayah non-pesisir lebih rendah daripada konsumsi ikan di wilayah pesisir, tetapi data ini menunjukkan dengan peningkatan konsumsi ikan pada ibu hamil di wilayah non-pesisir dapat meningkatkan berat dan panjang lahir bayi. Oleh karena itu, ibu hamil di wilayah non-pesisir sangat penting untuk meningkatkan konsumsi ikannya karena berdasarkan analisis, peningkatan konsumsi ikan di wilayah non-pesisir sensitif terhadap penambahan berat dan panjang lahir bayi sementara di wilayah pesisir hanya sensitif terhadap berat lahir bayi.

Namun, secara total konsumsi ikan ibu berpengaruh terhadap berat, panjang, dan lingkar kepala lahir bayi. Bersama tinggi badan ibu, konsumsi ikan berpengaruh terhadap berat lahir bayi. Ibu dengan tinggi badan yang lebih rendah memiliki risiko kematian bayi dan berat lahir bayi yang rendah pula. Hal ini menunjukkan adanya pengiriman zat gizi dan penyakit ibu selama masa kecilnya terhadap kesehatan bayinya yang tergambar dalam tinggi badan ibu. ${ }^{27}$ Sementara itu, penelitian sebelumnya menunjukkan bahwa peningkatan konsumsi ikan ibu dapat meningkatkan pertumbuhan janin. ${ }^{30}$ Penelitian lain menunjukkan peningkatan berat dan lingkar kepala lahir seiring dengan peningkatan konsumsi ikan ibu. ${ }^{20,21}$ Pengaruh konsumsi ikan ibu terhadap berat lahir bayi utamanya karena kandungan lemak pada ikan.,13,20 Penambahan berat, panjang, dan lingkar kepala lahir bayi dapat dijelaskan karena kandungan omega-3 dalam ikan yang mungkin akan mengganggu prostaglandin yang terlibat dalam proses persalinan sehingga memperpanjang durasi kehamilan dan juga dengan cara menurunkan viskositas darah sehingga aliran darah dan zat gizi ke plasenta terpenuhi dengan baik, dengan demikian pertumbuhan janin dapat meningkat. ${ }^{2}$ Selain itu, ikan juga merupakan sumber dari beberapa zat gizi yang penting untuk perkembangan janin, seperti iodium. Iodium merupakan bahan baku hormon tiroid. Hormon ini berperan untuk pertumbuhan dan perkembangan. ${ }^{31}$ Pengaruh konsumsi ikan ibu dengan lingkar kepala lahir mungkin juga karena kandungan asam lemak tak jenuh ganda terutama asam lemak omega-3, EPA (eicosapentaenoic acid) dan DHA (docosahexaenoic acid) yang terkandung dalam ikan sehingga konsumsi ikan ibu yang cukup selama kehamilan menunjukkan perkembangan syaraf bayi yang lebih baik., ${ }^{2,14,15}$

Konsumsi ikan dan kontribusi lemak ikan 
terhadap asupan lemak total ibu yang lebih tinggi di wilayah pesisir juga sejalan dengan berat dan lingkar kepala lahir bayi yang lebih tinggi di wilayah pesisir. Sehingga konsumsi ikan dapat mejadi salah satu alternatif dalam upaya pebaikan gizi anak utamanya dalam penurunan kejadian BBLR. Karena konsumsi ikan di trimester ketiga terkait erat dengan berat badan bayi lahir, dimana risiko terjadinya BBLR telihat lebih tinggi saat konsumsi ikan ibu yang rendah pada trimester tiga kehamilan. $^{1}$

\section{KESIMPULAN DAN SARAN}

Konsumsi ikan, kontribusi lemak ikan terhadap asupan lemat total ibu, berat dan lingkar kepala lahir bayi lebih tinggi dan signifikan di wilayah pesisir dibanding wilayah non-pesisir. Terdapat hubungan positif antara tinggi badan ibu dengan berat dan panjang badan lahir. Terdapat hubungan yang positif antara konsumsi ikan ibu dengan berat, panjang, dan lingkar kepala lahir bayi. Konsumsi ikan dan tinggi badan ibu merupakan faktor yang memengaruhi berat lahir bayi. Konsumsi ikan ibu juga berpengaruh terhadap panjang dan lingkar kepala lahir bayi. Perlu peningkatan asupan energi bagi ibu hamil di kedua wilayah serta peningkatan konsumsi ikan ibu di wilayah non-pesisir, hal ini bisa dilakukan salah satunya dengan pendidikan gizi dan memasyarakatkan gemar makan ikan bagi ibu hamil. Ikan dapat dijadikan sebagai pangan sumber protein yang baik untuk memenuhi kebutuhan saat kehamilan. Perlu diadakan penelitian lanjutan untuk melihat faktor-faktor lain yang berpengaruh terhadap outcome kelahiran.

\section{UCAPAN TERIMA KASIH}

Ucapan terimakasih disampaikan kepada: 1) Neys-van Hoogstraten Foundation-Netherlands, 2) Badan Kesatuan Bangsa dan Politik Provinsi Jawa Timur dan Kabupaten Sumenep, 3) Dinas Kesehatan Kabupaten Sumenep, 4) Puskesmas Lenteng, Puskesmas Moncek, Puskesmas Kalianget Kabupaten Sumenep.

\section{DAFTAR PUSTAKA}

1. Muthayya S, Dwarkanath P, Thomas T, Ramprakash S, Mehra R, Mhaskar A, Mhaskar R, Thomas A, Bhat S, Vaz M, Kurpad AV. The Ef- fect of Fish and Omega 3 LCPUFA Intake on Low Birth Weight in Indian Pregnant Women. European Journal of Clinical Nutrition. 2009; 63: 340-346.

2. Mohanty BP, Ganguly S, Karunakaran D, Chakraborty K, Sharma AP, Mohapatra PKR, Nayak NR . Maternal Fish Consumption and Prevention ff Low Birth Weight in the Developing World. National Academy Science Letters. 2012; 35(5):433-438.

3. Kemenkes RI. Buku Studi Diet Total: Survei Konsumsi Makanan Individu Indonesia 2014. Jakarta: Kementrian Kesehatan RI; 2014.

4. Kemenkes RI. Riset Kesehatan Dasar 2013. Jakarta: Kementrian Kesehatan RI; 2013.

5. Kementan RI. Outlook Komoditas Pertanian Subsektor Peternakan Daging Sapi. Jakarta: Kementrian Pertanian RI; 2015.

6. Kementan RI. Outlook Komoditas Pertanian Subsektor Peternakan Daging Ayam. Jakarta: Kementrian Pertanian RI; 2015.

7. Kementan RI. Outlook Komoditas Pertanian Subsektor Peternakan Telur. Jakarta: Kementrian Pertanian RI; 2015.

8. Kementan RI. Outlook Komoditas Pertanian Subsektor Peternakan Susu. Jakarta: Kementrian Pertanian RI; 2015.

9. KKP RI. Keragaan Perikanan Tangkap 2015. Jakarta: Kementrian Kelautan dan Perikanan RI; 2015.

10. KKP RI. Kelautan dan Perikanan dalam Angka 2013. Jakarta: Kementrian Kelautan dan Perikanan RI; 2013.

11. Dinas Kelautan dan Perikanan Kabupaten Sumenep. Rekam Jejak Pembangunan Kelautan dan Perikanan di Kabupaten Sumenep. Sumenep: Dinas Kelautan dan Perikanan Kabupaten Sumenep; 2014.

12. Dinkes Kabupaten Sumenep. Profil Kesehatan Kabupaten Sumenep Tahun 2014. Sumenep: Dinas Kesehatan Kabupaten Sumenep; 2014.

13. Larsen SC, Ängquist L, Laurin C, Morgen CS, Jakobsen MU, Paternoster L, Smith GD, O1sen SF, Sørensen TIA2, Nohr EA. Association between Maternal Fish Consumption and Gestational Weight Gain: Influence of Molecular Genetic Predisposition to Obesity. Plos One. 2016;11(3): e0150105.

14. Hibbeln JR, Davis JM, Steer C, Emmett P, 
Rogers I, Williams C, Golding J. Maternal Seafood Consumption in Pregnancy and Neurodevelopmental Outcomes in Childhood: An Observational Cohort Study. Lancet. 2007;369:578-85.

15. Starling P, Charlton K, McMahon AT, Lucas C. Fish Intake during Pregnancy and Foetal Neurodevelopment - A Systematic Review of the Evidence. Journal Nutrient. 2015;7:20012014.

16. Kusuma R. Analisis Kontribusi Konsumsi Ikan terhadap Kecukupan Energi dan Zat Gizi Ibu Hamil di Bogor [Skripsi]. Bogor: Institut Pertanian Bogor; 2012.

17. Diana R, Rachmayanti RD, Anwar F, Khomsan A, Christianti DF, Kusuma R. Dietary Intake, Nutritional Status, Traditional Beliefs and Practices of Pregnant Women in Madura Island [Proposal Penelitian]. Universitas Airlangga Surabaya; 2016.

18. Rachmat M. Buku Ajar Biostatistika: Aplikasi pada Penelitian Kesehatan. Jakarta: Penerbit Buku Kedokteran EGC; 2012.

19. Fadilla M. Keragaan dan Determinan Status Gizi dan Kesehatan Penduduk Lokal Timika Berdasarkan Agroekologi [Tesis]. Bogor: Institut Pertanian Bogor; 2002.

20. Brantsæter AL, Birgisdottir BE, Meltzer HM, Kvalem HE, Alexander J, Magnus P, Haugen M. Maternal Seafood Consumption and Infant Birth Weight, Length and Head Circumference in the Norwegian Mother and Child Cohort Study. British Journal of Nutrition. 2012;107:436-444.

21. Leventakou V, Roumeliotaki T, Martinez D, Barros H, Brantsaeter AL, Casas M, Charles MA, Cordier S, Eggesbø M, van Eijsden M et al. . Fish Intake during Pregnancy, Fetal Growth, and Gestational Length in 19 European Birth Cohort Studies. American Journal of Clinical Nutrition. 2014; 99: 506-16.

22. Paramita S, Sharma N, Benjamin AI. Risk Factors for Low Birth Weight: A Case Control Study in Ludhiana, Punjab. Indian Journal of Maternal \& Child Health. 2009;11:1-4.

23. Budijanto D. Determinan ' 4 Terlalu' Masalah Kesehatan Reproduksi Hubungannya dengan Penggunaan Alat KB Saat Ini di Indonesia. Buletin Jendela Data dan Informasi Keseha- tan. 2013;2(2).

24. Suparmi, Chierra B, Pradono J. Low Birth Weight and Neonatal Mortality in Indonesia. Health Science Journal of Indonesia. 2016;7(2).

25. Ye R, Pei L,Ren A, Zhang Y, Zheng X, Liu J. Birth Weight, Maternal Body Mass Index, and Early Childhood Growth: A Prospective Birth Cohort Study in China. Jurnal Epidemiol. 2010;20 (6): 421-428.

26. Veena SR, Gale CR, Krishnaveni GV, Kehoe SH, Srinivasan K, Fall CHD. Association between Maternal Nutritional Status in Pregnancy and Offspring Cognitive Function during Childhood and Adolescence; A Systematic Review. BMC Pregnancy and Childbirth. 2016;16:220.

27. Özaltin E, Hill K, Subramanian SV.Association of Maternal Stature with Offspring Mortality, Underweight, and Stunting In Low- to Middle-Income Countries. Journal of the American Medical Association. 2010;303(15).

28. Shah PS. Parity and Low Birth Weight and Preterm Birth: A Systematic Review and Meta-Analyses. Acta Obstetricia et Gynecologica. 2010;89:862-875.

29. Durrani AM, Rani A. Effect of Maternal Dietary Intake on the Weight of the Newborn in Aligarh City, India. Nigerian Medical Journal. 2011;52(3).

30. Rogers I, Emmett P, Ness A, Golding J, ALSPAC Study Team. Maternal Fish Intake in Late Pregnancy and the Frequency of Low Birth Weight and Intrauterine Growth Retardation in a Cohort Of British Infants. Journal Epidemiol Community Health. 2004;58:486492.

31. Simpson JL, Bailey LB, Pietrzik K, Shane B, Holzgreve W. Micronutrients and Women of Reproductive Potential: Required Dietary Intake and Consequences of Dietary Deficienty or Excess. Part II-Vitamin D, Vitamin A, Iron, Zinc, Iodine, Essential Fatty Acids. Journal of Maternal-Fetal \& Neonatal Medicine. $2011 ; 24(1): 1-24$. 